\title{
Figurative Language in Westlife Album "Coast to Coast" and My Chemical Romance Album "Welcome To Black Parade"
}

\author{
I.A Intan Gayatri Manuaba ${ }^{*}$, I Ketut Tika ${ }^{2}$ \\ ${ }^{[123]}$ English Departement - Faculty of Arts - Udayana University \\ [intangayatri3@gmail.com] ${ }^{2}$ [ketuttika53@gmail.com] \\ *Corresponding Author
}

\begin{abstract}
This study is entitled "Figurative Language in Westlife Album "Coast to Coast" and My Chemical Romance Album 'Welcome to Black Parade". The problems formulated in this study are the types of figurative language employed in Westlife's and My Chemical Romance's song lyrics and to find out how is the meaning of figurative language contrasted with its lexical meaning. There were five songs of Westlife chosen to be the source of first data, namely; Againts All Odds, I Lay My Love on You, My Love, What Makes a Man, and When You're Looking Like That and five songs of My Chemical Romance also chosen to be the source of second data, namely; I Don't Love You, The Sharpest Live, This How I Disappear, MAMA, and Welcome to Black Parade. The data were collected using documentation method then they were analyzed through qualitative method. After the data were analyzed and discussed, it was found that there were seven kinds of figure of speech employed in all the ten song lyrics; they were Simile, Personification, Hyperbole, Metonymy, Irony, Metaphor and Paradox. And then we find out the meaning of figurative language contrasted with its lexical meaning
\end{abstract}

Keywords:figurative language, lexical meaning, and lyric

\begin{abstract}
Abstrak
Judul dari artikel ini adalah "Bahasa Kiasan dalam Album Westlife "Dari Sisi ke Sisi" dan Album My Chemical Romance "Selamat Datang di Parade Hitam". Masalah yang muncul dalam skripsi ini adalah tipe-tipe dari bahasa kiasan yang ada di dalam lirik lagu Westlife dan My Chemical Romance dan untuk mencari tau bagaimana arti dari bahasa kiasan berlawanan dengan arti leksikalnya. Terdapat lima lagu Westlife yang dipilih untuk menjadi data pertama, yang berjudul;Melawan Segala Rintangan, Aku Meletakkan Cintaku Padamu, Cintaku, Apa yang Membuat Seorang Pria, dan Ketika Kau Terlihat Seperti Itu dan lima lagu yang dipilih dari album My Chemical Romance, yang berjudul; Aku Tidak Mencintaimu, Hidup yang Tajam, Beginilah Cara Saya Menghilang, MAMA, dan Selamat Datang di Parade Hitam. Data didapatkan menggunakan teknik dokumentasi dan data di analisis menggunakan metode kualitatif. Setelah data di analisis dan didiskusi, ditemukan tujuh tipe dari bahasa kiasan dalam sepuluh lagu, mereka adalah; Simil, Personifikasi, Hiperbola, Metonimi, Ironi, Metafora dan Paradok. Dan telah ditemukan arti dari bahasa kiasan yang berlawanan dengan arti leksikalnya.
\end{abstract}

Kata kunnci: bahasakiasan, arti leksikal, dan lirik. 


\section{Background of The Study}

According to Knickerbocker and Reninger (1963), figurative language is a language that can describe something or an inanimate object as life. It requires imagination to understand what meaning is conveyed by the author. Figurative language is widely used in various literary works, because if they do not use figurative language, then the literary works will not be alive or boring. (Nana Lusiana, 2017, p.1).A song is a composition of voices performed by singing. Figurative language is most widely used in a song because a song is like poetry, every line of the words has meaning. The difference between a song and a poem is that when present a poem the voice is adapted to the theme of the poem. The song is also adapted to the theme of the song, but also accompanied by a beautiful and similar rhythm. The vocal group of Westlife is a group whose fame is well known to the world, the personells of this group consist five handsome men with a very melodious voice but with the passage of time now only have four personnel. Westlife has many albums, but the most recognizable album is the "Coast to Coast" album, consisting of five popular song. The beautiful lyrics in five songs packed in one album are successfully catching the listener and dragging their imagination into used of the figurative languages in the songs. Different from Westlife, My Chemical Romance is a vocal rock group consist of five men who have very eccentric style. My Chemical Romance has many albums, but the most famous album is "Welcome to The Black Parade" album, consisting of ten popular songs. The unique lyrics in the album succeeded hypnotize listeners and make My Chemical Romance has it is own place in the hearts of his fans.

\section{Problems of The Study}

Based on the background above, there are two problems that can be formulated in this study:

a. What types of figurative language are used in Weslife's song and My Chemical Romance's song ?

b. How is the meaning of figurative language contrasted with its lexical meaning ?

\section{Aims of the study}

According to the problems, the aims of the study are as follows:

a. To identify the types of figurative language found in Westlife's song and My Chemical Romance's song.

b. To find out how the meaning of figurative language contrasted with its lexical meaning.

\section{Research Method}

The research method in this study is classified into three parts, they are : data source, method and technique of collecting data, and also method and technique of analyzing data.

\subsection{Data Source}

The first data of this study were taken from the one of the Westlife's album entitled "Coast to Coast" which was released in 2000. This album is a compilation album of the Westlife's songs. Five songs were chosen to be analyzed in this study. Those songs entitled Againts All Odds, My Love, What Makes a Man, I Lay My Love on You and When You're Looking Like That. Those songs were chosen because the lyrics of the songs contain many kinds of figurative language and have a different meaning. And the second data if this study were taken from the one of the My Chemical Romance's album entitled 
"Welcome to The Black Parade" which was released in 2006. This album is a compilation album of the My Chemical Romance's songs. Five songs were chosen to be analyzed in this study. Those songs entitled This How I Disappear, I Don't Love You, The Sharpest Live, MAMA, and Welcome to The Black Parade. Those songs were chosen because the lyrics of the songs contain many kinds of figurative language and have a different meaning

\subsection{Method and Technique of Collecting Data}

The data of this study was collected through documentation method. There were several steps in collecting the data. First, five songs were chosen from the Westlife's album "Coast to Coast" and from the My Chemical Romance's album "Welcome to The Black Parade" . Second, the songs were downloaded from the internet. Then, listen to the song slowly and repeat it to find out the message of the songs. Finally, the important points which related to figurative language and its meaning were noted down.

\subsection{Method and Technique of Analyzing Data}

The collected data were analyzed using a qualitative method based on the theories applied in this study. There were several steps taken in analyzing the data. First, the data were classified based on their types of figurative language. Next, the types of figurative language found in the data were analyzed. Finally, the meaning of the figurative language in the song lyrics was identified and analyzed. The data were analyzed based on the theory proposed by Knickerbocker and Reniger (1963) and the theory proposed by Abdul Chaer (2013:59).

\section{Analysis}

\subsection{Westlife Album "Coast to Coast" song entitled "My Love" \\ Lyric}

An empty street, an empty house (1)

A hole inside my heart (2)

I'm all alone, the rooms are getting smaller. (3)

I wonder how, I wonder why, (4)

I wonder where they are (5)

The days we had, the songs we sang together, oh, yeah. (6)

And all my love, I'm holding on forever (7)

Reaching for the love that seems so far (8)

So I say a little prayer (9)

And hope my dreams will take me there (10)

Where the skies are blue to see you once again, my love.(11)

Over seas from coast to coast (12)

To find the place I love the most (13)

Where the fields are green to see you once again, my love. (14)

I try to read, I go to work (15)

I'm laughing with my friends (16)

But I can't stop to keep myself from thinking, oh, no. (17)

I wonder how, I wonder why, (18)

I wonder where they are (19)

The days we had, the songs we sang together, oh, yeah. (20)

And all my love, I'm holding on forever (21)

Reaching for the love that seems so far (22)

So I say a little prayer (23) 
And hope my dreams will take me there (24)

Where the skies are blue to see you once again, my love. (25)

Over seas from coast to coast (26)

To find the place I love the most (27)

Where the fields are green to see you once again, (28)

To hold you in my arms, (29)

To promise you my love, (30)

To tell you from the heart, (31)

You're all I'm thinking of. (32)

Reaching for the love that seems so far (33)

So I say a little prayer (34)

And hope my dreams will take me there (35)

Where the skies are blue to see you once again, my love. (36)

Over seas from coast to coast (37)

To find the place I love the most (38)

Where the fields are green to see you once again, my love. (39)

Say a little prayer (my sweet love) (40)

Dreams will take me there (41)

Where the skies are blue (woah, yeah) (42)

To see you once again, my love. (oh, my love) (43)

Over seas from coast to coast (44)

To find the place I love the most (45)

Where the fields are green to see you once again, my love. (46)

\subsection{Analysis}

\section{A hole inside my heart (line 2)}

The sentence above shows the use of hyperbole because it seems to be excessive. In lexical meaning "hole" means opening or hollow place in a solid body (Oxford 1985). The author doesn't really have a hole inside his heart, but it is just a phrase that illustrates that his heart is empty because someone is away from him. So to refill the void or a hole inside his heart, the author expects someone to close the hole back.

I'm all alone, the rooms are getting smaller (line 3)

The sentence above shows the use of personification because it is giving human characteristic to an object, animal, or an abstract idea. In lexical meaning, "rooms" means part of a house or other building enclosed by walls or partitions, floor and ceiling (Oxford 1985) and "smaller" means of a size that is less than normal or usual (Oxford 1985). Actually, room is an inanimate object which is actually can't get smaller but life object can. In this sentence, the writer wants to convey how tortured when alone and want to meet his love immediately. When he has met his love, he is not alone and will not feel the rooms getting smaller.

And all my love, I'm holding on forever (line 7)

The sentence above shows the use of hyperbole because it seems to be excessive. In lexical meaning "forever" means for all future time, for always, a very long time (Oxford 1985). In fact, there's nothing hold for all future time or a very long time, the author just wants to convey how he is falling in love with someone so want to hold on forever which means to always be with him and do not want to be separated.

\section{Reaching for the love that seems so far} (line 8)

This sentence shows the use of hyperbole because it seems to be excessive. In lexical meaning "far" means indicating a great distance (Oxford 1985). In this point, the author doesn't really say that want to reach the that is very far distance. Reaching for the love that seems so far mean someone who has not realized how much the author loves the person. 


\section{And hope my dreams will take me there (line 10)}

This line shows the use of hyperbole as an excessive used to emphasize a point. In lexical meaning, "dreams" means which one seems to see or experience during sleep (Oxford 1985). In this point, the author doesn't really say the dream can take him away, wherever he wants. But the line means that he hopes in a dream he can meet someone he hopes for. After he meets with someone he expects, he thinks to have carried himself wherever he wants, because, for the author, she is a very beautiful dream.

Where the skies are blue to see you once again, my love (line 14)

The sentence above shows the use of hyperbole as an excessive used to accentuate a point. In lexical meaning "skies" means sky, and "blue" means coloured like the sky on a clear day or the deep sea when the sun is shining (Oxford 1985). In this case, the author expressed a desire to meet someone is when the sky looks very blue. The sky looks very blue has a meaning when the atmosphere is romantic and fun, then at that romantic moment is the right time to meet the loved ones.

\section{Overseas from coast to coast (line 26)}

The sentence above shows the use of hyperbole because it seems to be excessive. In lexical meaning, "coast" means land bordering the sea, seashore and land near it (Oxford 1985). In this point, the author doesn't want to actually overseas a large ocean to meet someone, because it is impossible and greatly exaggerated. The intended meaning of the author in this line is, he will pass the obstacle to meet with someone, even though the obstacle is very difficult to pass.

\section{Conclusions}

Based on the foregoing analysis and discussion, the following points can be concluded:

At the end of the discussion, it generates two conclusions based on the two problems of study. First, we can conclude there is various figurative language contained Westlife album "Coast to Coast", such as simile, personification, hyperbole, metonymy, and paradox. And also we can conclude there are many various figurative languages contained in My Chemical Romance album "Welcome to Black Parade", such as irony, hyperbole, paradox, personification, and metaphor. The figurative language that is most abundant in this Westlife album "coast to coast" is hyperbole same like figurative language most abundant in the My Chemical Romance album "Welcome to Black Parade" is hyperbole because the songs contained in this two album use the excessive language to entertain the fans. And the difference between the two musical genres is in the song Westlife contains simile as figurative language because in the Westlife songs often presupposes a woman as an angel or as a flower whereas in My Chemical Romance song no one contains simile but contains metaphor as figurative language because My Chemical Romance often presupposes dead objects as life while in the songs of Westlife does not contain metaphor as figurative language. Second, the contrasted or the difference between figurative language and lexical meaning is figurative language using a style of language that seems interesting but sometimes difficult to understand if we don't review the contents of sentences that have figurative language. While lexical meaning useS the aspect of meaning usually given in the dictionary. Important aspects in describing lexical meaning are syntagmatic relations 
holding between particular lexical items (bird:fly, blond:hair), as well as a paradigmatic relation between words which have a similar meaning (red:blue).

\section{Bibliography}

Ayu. 2005. Analysis of Figurative Language in the Poem. Denpasar: English Department, Faculty of Letters, Udayana University.

Agus. 2008. Analysis of Figurative Language in Song Lyrics of Story of the Year Band. Denpasar: English Department, Faculty of Letters, Udayana University.

Chaer, Abdul. 2013. Pengantar Semantik Bahasa Indonesia. Jakarta: Rineka Cipta.

Hornby. 1985. Oxford Advanced Learner's Dictionary of Current English. British: Oxford University.

Knickerbocker \&Reninger. 1963. Interpreting Literature. USA:Holt Rinehart and Winston, Inc.

Leech. 1974. Semantics. Auckland: Penguin Books.

Lusiana, Nana. Figurative Language Used in Taylor Swift's Songs in the Album 1989. Denpasar: English Department, Faculty of Letters, Udayana University.

Westlife: Coast to Coast. Lyric Interpretation. November 6, 2000. Web. Accessed on March 29, 2018. https://www.google.com/search?q= westlife+coast+to+coast\&ie $=$ utf$\underline{8 \& o e=u t f-8}$ 